\title{
IDENTIFIKASI KEPUASAN FOOD TRAVELLER PADA RUMAH MAKAN SARI RASA KABUPATEN ENDE (STUDI DESKRIPTIF PADA WEBSITE TRIPADVISOR)
}

\author{
Oleh \\ 1) Yulius Laga, S.E., M.Ec.Dev \\ Dosen Program Studi Manajemen \\ e-mail:yuliuslaga@uniflor.ac.id \\ 2) Santy Permata Sari, S.AB, MM \\ Dosen Prodi Manajemen \\ e-mail: santypermata66@gmail.com
}

\begin{abstract}
ABSTRAK
Riset ini merupakan hasil review wisatawan makanan di situs Tripadvisor dari tahun 2014 hingga tahun 2020. Review dilakukan di Kabupaten Sari Rasa Ende dengan 154 reviewer. Metode penelitian dilakukan dengan Statistik Deskriptif dengan Alat Analisis SPSS 20. Hasil penelitian menunjukkan bahwa kondisi Restoran Sari Rasa saat ini telah menjadi ikon bagi wisatawan makanan dan wisatawan khususnya untuk menikmati menu makanan lokal dengan citarasa yang khas, hal yang perlu dijaga adalah pelayanan perhotelan, termasuk komunikasi yang baik dan keaslian lokalnya. menu makanan, di sisi lain perlu ditingkatkan kualitas rasa yang disesuaikan dengan karakteristik wisatawan, porsi makanan yang ditawarkan juga harus disesuaikan dengan pola konsumsi pengunjung, serta kualitas dan suasana restoran. kamar dan fasilitas yang perlu ditingkatkan.
\end{abstract}

Kata kunci: wisatawan makanan, peringkat, kepuasan, restoran.

\section{ABSTRACT}

This research is the result of a food traveler review on the Tripadvisor website from 2014 to 2020. The review was conducted at Sari Rasa Ende Regency, with 154 reviewers. The research method was carried out with Descriptive Statistics with SPSS 20 Analysis Tool. The results showed that the current condition of Sari Rasa Restaurant has become an icon for food travelers and tourists specifically to enjoy local food menus with distinctive flavors, the thing that needs to be maintained is hospitality services, including good communication and the authenticity of the local food menu, on the other hand need to be improved in the quality of taste that is tailored to the characteristics of tourists, the portion of food offered must also be adjusted to the pattern of visitor consumption, as well as the quality and atmosphere of the room and facilities that need to be improved.

Keywords: food traveler, rating, satisfaction, restaurant. 
IDENTIFIKASI KEPUASAN FOOD TRAVELER PADA RUMAH MAKAN SARI RASA KABUPATEN ENDE (STUDI DESKRIPTIF PADA WEBSITE TRIPADVISOR) -

1)Yulius Laga, 2) Santy Permata Sari

\section{Pendahuluan}

Bisnis rumah makan, kedai atau warung, restoran dan sejenisnya merupakan model bisnis yang berkesinambungan sebab memanfaatkan kebutuhan dasar manusia untuk makan. Kebutuhan bisnis rumah makan seperti ini, membutuhkan penilaian dalam hal kualitas pelayanan maupun kualitas produk yang dihasilkan pada kasus ini menunjukan kualitas makanan yang tawarkan pada konsumen, harapannya kualitas pelayanan dan produk memberikan dampak kepuasan pada konsumen untuk terus menggunakan jasa/produk dari warung makan tersebut, yang memungkinkan adanya proses secara berkesinambungan. Penelitian (Utami \& Jatra, 2015), (Afrizal, 2018) menunjukan bahwa kepuasan berpengaruh positif dari tindakan fisik yang dapat diukur/dinilai (tangible), dapat diandalkan, memiliki daya tanggap, memiliki jaminan dan empati serta keterjangkauan harga dalam memenuhi kebutuhannya.

Bisnis rumah makan di Kabupaten Ende merupakan bagian dari serangkaian sumber pendapatan yang tidak hanya dinikmati sebagai pengusaha rumah makan, disisi lain juga sebagai bagian dari pendapatan daerah, berdasarkan data BPS Kabupaten Ende yang tercatat pada data Badan Pendapatan Daerah Kabupaten Ende pada tahun 2020 terdapat 182 rumah makan dengan estimasi pendapatan dari pajak sebesar 10 persen dari pendapatan dengan estimasi 5 juta perbulan untuk tiap rumah makan, maka pendapatan dari pajak sebesar sebesar 91 juta rata-rata perbulan bagi Kabupaten Ende. Hal ini memungkinkan bisnis rumah makan menjadi sarana baru baik bagi pemerintah maupun masyrakatnya dalam mengembangkan usaha yang berkelanjutan.

Penelitian ini menjadi penting dan perlu dilakukakan pertama, karena melihat kondisi banyaknya hasil review yang dilakukan wisatawan pada rumah makan Sari Rasa, jika dibandingkan dengan rumah makan/restoran lainnya diwilayah Kabupaten Ende. Kedua, Standar review yang diberikan oleh wisatawan yang sekaligus sebagai contributor pada website Tripadvisor memberikan dampak pada tingkat kunjungan food traveller yang datang kerumah makan Sari Rasa Kebupaten Ende. Ketiga Warung Makan Sari Rasa menjadi icon bagi food traveller sekaligus wisatawan yang datang ke wilayah Kabupaten Ende. Penelitian ini juga memanfaatkan akses Website Tripadvisor untuk melihat dan menganalisis hasil review konsumen yang pernah berkunjung ke Warung Makan Sari Rasa. Website ini juga memberikan penilaian (rating) sebagai hasil evaluasi konsumen, umumnya pengunjung yang datang ke Rumah Makan Sari Rasa merupakan wisatawan domestic (dalam negeri) dan mancanegara. Pada website ini wisatawan memberikan 
IDENTIFIKASI KEPUASAN FOOD TRAVELER PADA RUMAH MAKAN SARI RASA KABUPATEN ENDE (STUDI DESKRIPTIF PADA WEBSITE TRIPADVISOR) -

1)Yulius Laga, 2) Santy Permata Sari

komentar dan review terhadap aspek-aspek yang mempengaruhi kepuasnnya terhadap jasa pelayanan dan menu makanan yang disiapkan pada Rumah Makan Sari Rasa.

\section{Kajian Pustaka}

\subsection{Food Traveler}

Defenisi food traveller secara umum merupakan orang yang sedang melakukan aktivitas liburan dengan memanfaatkan kegiatan untuk menikmati makanan khas atau kuliner tradisional pada berlibur disuatu daerah atau wilayah yang dijadikan sebagai tujuan, disisi lain food traveller juga memanfaatkan media sosial sebgai wadah untuk memerikan review dan rating dari pengalaman perjalanannya selama liburan. Penelitian (Björk \& Kauppinen-Räisänen, 2019) juga mendukung adanya implikasi untuk tujuan dan manajemen pariwisata, studi ini menyarankan penekanan yang lebih kuat pada makanan lokal sebagai dimensi pemasaran, melibatkan masyarakat lokal dengan membuat mereka sadar akan peran mereka dalam lanskap tujuan panganan lokal dan pentingnya untuk menambah pengalaman wisatawan sebagai bentuk pemasaran, serta menciptakan ruang tujuan publik-swasta di mana wisatawan dapat memiliki lebih banyak pengalaman pada panganan lokal.

\subsection{Bisnis Rumah Makan}

Keputusan Menteri Pariwisata, Pos dan Telekomunikasi No.KN.73/PVVI05/MPPT85 tentang Peraturan usaha Rumah Makan bisnis rumah makan merupakan usaha yang menyediakan jasa pelayanan makanan dan minuman yang dikelola secara komersial. Pengertian rumah makan secara konkrit menurut Marsum W.A (2005) dalam (Firdaus, 2016) sebagai tempat yang terorganisisr secara komersial memberikan pelayanan yang baik kepada tamu berupa kegiatan makan dan minum.

\subsection{Review dan Rating Rumah Makan}

Review dan rating pada rumah makan merupakan sebuah ulasan secara ringkas dan tinjauan. Dapat disebut sebagai pemeriksaan teks yang mempunyai sebuah makna teks dan memiliki fungsi sebagai memberikan kritik, penilaian, karya seni, atau respons terhadap suatu kegiatan tersebut, serta produk kepada pendengar atau pembaca secara khusus pada website TripAdvisor, sedangkan rating merupakan nilai kumulatif yang diperoleh oleh salah satu jenis layanan seperti: hotel, rumah makan atau restoran dan tempat wisata yang merupak hasil review para contributor. Secara umum seorang kontributor merupakan penulis artikel atau kolumnis yang menyumbangkan tulisannya 
IDENTIFIKASI KEPUASAN FOOD TRAVELER PADA RUMAH MAKAN SARI RASA KABUPATEN ENDE (STUDI DESKRIPTIF PADA WEBSITE TRIPADVISOR) -

1)Yulius Laga, 2) Santy Permata Sari

berupa berita, informasi, atau opini berdasarkan fakta-fakta yang ada kepada suatu media dan bersifat tidak terikat pada media tersebut. (Wirangga et al., 2016) Penilaian yang dapat diberikan oleh reviewer seperti pada rasa, lingkungan, layanan, kebersihan dan juga harga dari rumah makan yang pernah dikunjungi sebelumnya. Reviewer juga dapat merekomendasikan rumah makan yang memang belum terdapat pada aplikasi dengan mengirimkan informasi lewat aplikasi ini. Informasi tersebut nantinya akan sampai kepada admin sistem, kemudian admin sistem akan melakukan observasi akan kebenaran dari informasi tersebut sehingga nantinya akan didapat data yang lebih akurat.

\subsection{Kepuasan Layanan Makanan}

Penelitian (Utami \& Jatra, 2015), (Afrizal, 2018) menunjukan bahwa kepuasan dipengaruhi 5 dimensi dari kualitas pelayanan yang terdiri dari bukti fisik, kehandalan, daya tanggap, jaminan, dan empati. Penelitian lainnya (Muhtarom et al., 2015), (Situmeang, 2017) menunjukan bahwa kepuasan layanan pada warung makan dipengaruhi oleh kualitas pelayanan dan keterjangkauan harga, sedangkan lokasi rumah makan tidak berpengaruh terhadap kepuasan layanan, sedangkan (Khalida, 2018) menambahkan bahwa selain pengaruh kualitas pelayanan, harga dan lokasi, implikasi dari kepuasan juga akan mempengaruhi atau meningkatkan loyalitas.

\section{Metode Penelitian}

\subsection{Jenis Penelitian}

Deskriptif Kualitatif yang merupakan gambaran hasil penelitian berdasarkan hasil review dan penilaian wisatawan terhadap aspek kualitas pelayanan dan kualitas produk makanan yang disediakan di Rumah Makan Sari Rasa.

\subsection{Lokasi Penelitian Rumah Makan Sari Rasa}

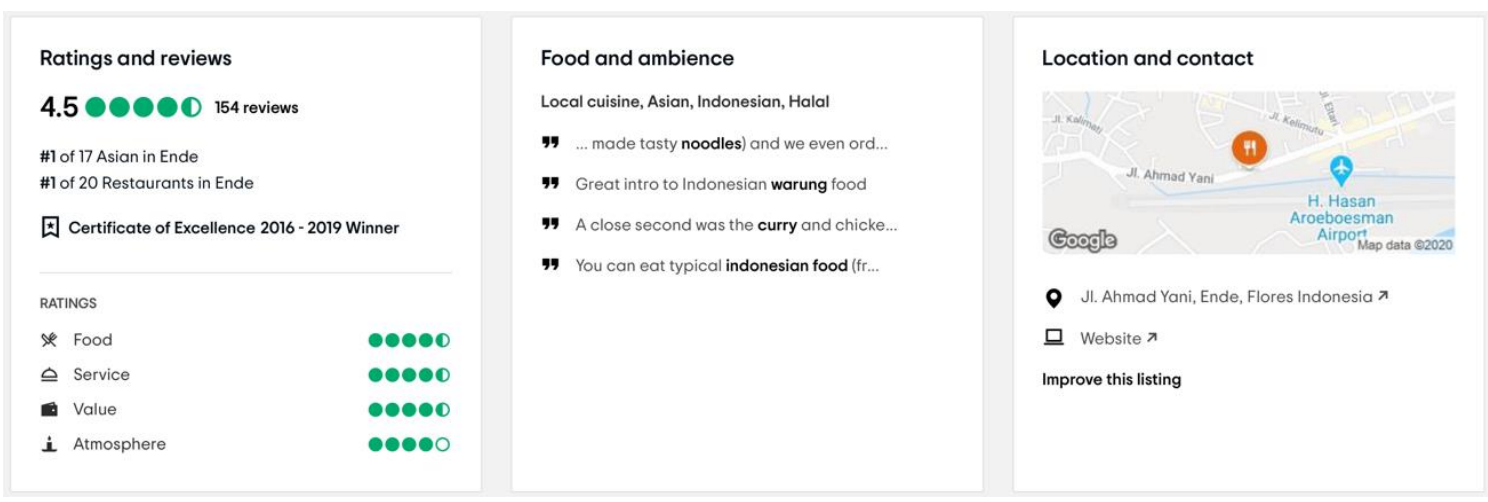

Sumber: https://www.tripadvisor.com (2020)

Gambar 1. Hasil Rating, Review, dan Lokasi Rumah Makan Sari Rasa 
IDENTIFIKASI KEPUASAN FOOD TRAVELER PADA RUMAH MAKAN SARI RASA KABUPATEN ENDE (STUDI DESKRIPTIF PADA WEBSITE TRIPADVISOR) -

1)Yulius Laga, 2) Santy Permata Sari

\subsection{Metode Pengumpulan Data}

Data pada penelitian ini, diperoleh dengan mengumpulkan dan menganalisis hasil review wisatawan pada Website Tripadvisor yang berkunjung di Rumah Makan Sari Rasa, Kabupaten Ende sebanyak 154 hasil review wisatawan dari tahun 2014 sampai dengan tahun 2020, yang merupakan kontributor dari Tripadvisor.

\subsection{Metode Analisis Data}

Analisis data dilakukan dengan menggunakan statistik deskriptif dengan alat bantu analisis SPSS 20. Analisis data dimulai dengan melakukan klasterisasi negara asal, level contributor dan nilai review yang diberikan oleh contributor pada Website TripAdvisor. Tahap berikutnya dianalisis nilai dan komentar reviewer yang diklasterisasi dalam bentuk atau pernyataan positif dan negatif terhadap Rumah Makan Sari Rasa.

\section{Hasil Penelitian dan Pembahasan}

4.1 Hasil Analisis Statistik Deskriptif

Tabel 1. Statistik Deskriptif Food Traveler pada Rumah Makan Sari Rasa

\begin{tabular}{|c|c|c|c|c|c|c|}
\hline \multicolumn{7}{|c|}{ Descriptive Statistics } \\
\hline & $\mathrm{N}$ & Range & Minimum & Maximum & \multicolumn{2}{|c|}{ Mean } \\
\hline & Statistic & Statistic & Statistic & Statistic & Statistic & Std. Error \\
\hline LevelCon & 154 & 6,00 &, 00 & 6,00 & 2,7468 &, 12584 \\
\hline Rating & 154 & 3,00 & 2,00 & 5,00 & 4,7273 &, 04811 \\
\hline Valid N (listwise) & 154 & & & & & \\
\hline
\end{tabular}

\section{Descriptive Statistics}

\begin{tabular}{|c|r|r|r|r|r|}
\hline Std. Deviation & Variance & \multicolumn{2}{|c|}{ Skewness } & \multicolumn{2}{c|}{ Kurtosis } \\
\hline Statistic & Statistic & Statistic & Std. Error & Statistic & Std. Error \\
\hline 1,56164 & 2,439 &, 690 &, 195 &,- 393 &, 389 \\
\hline, 59708 &, 357 & $-2,248$ &, 195 & 4,534 &, 389 \\
\hline & & & & & \\
\hline
\end{tabular}

Hasil analisis data statistik deskriptif menunjukan bahwa dari 154 review yang diberikan pada kunjungan di Rumah Makan Sari Rasa data semua responden valid, dengan nilai terendah dari rating yang diberikan adalah 3 dengan tingkat level contributor tertinggi dengan nilai 6. Nilai mean atau rata-rata responden pada level contributor sebesar 2,74 dan rata-rata rating yang diberikan sebesar 4,72. Apabila dibandingkan dengan nilai dari max rating yaitu 5 makan rating Rumah Makan Sari Rasa berada pada level sangat baik. 
IDENTIFIKASI KEPUASAN FOOD TRAVELER PADA RUMAH MAKAN SARI RASA KABUPATEN ENDE (STUDI DESKRIPTIF PADA WEBSITE TRIPADVISOR) -

1)Yulius Laga, 2) Santy Permata Sari

\subsection{Pemetaan Negara Asal Food Traveler}

Gambar 2. Data Negara Food Traveler yang datang ke Rumah Makan Sari Rasa

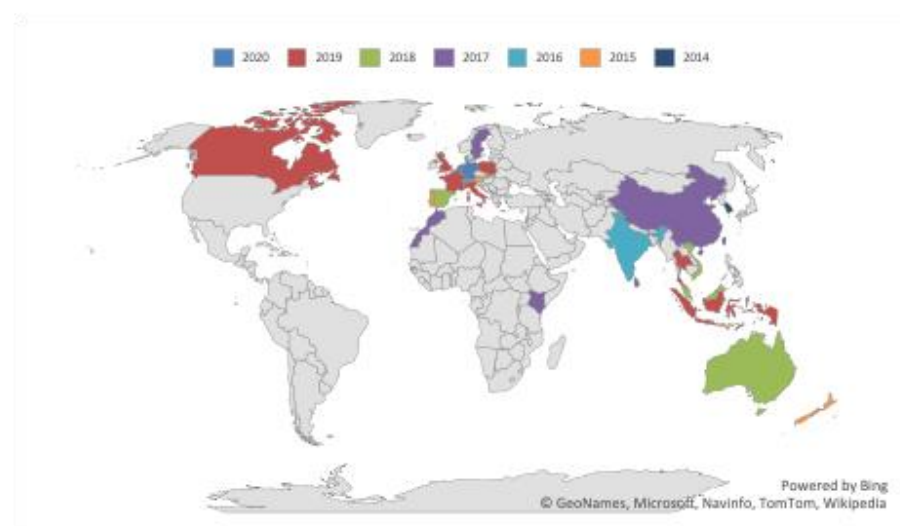

Sumber: Data Gambar Olahan Penulis dari : https://www.tripadvisor.com (2020)

Pada gambar 2 menunjukan sebaran selama 7 tahun hasil review dari food traveller lakukan pada website TripAdvisor menunjukan sebarannya lebih didominasi oleh negaranegara diwilayah Eropa dan diikuti negara-negara diwilayah Asia, seperti pada data yang ditampilkan Tabel 2. Banyaknya frekwensi yang datang ke Rumah Makan Sari Rasa sebesar 85 kali dan yang berasal dari Asia sebesar 52 kali diikuti Australia dan Amerika.

Tabel 2. Frekwensi Seberan Food Traveler berdasarkan Benua

\begin{tabular}{|r|c|c|c|c|}
\hline & Frequency & Percent & $\begin{array}{c}\text { Valid } \\
\text { Percent }\end{array}$ & $\begin{array}{c}\text { Cumulative } \\
\text { Percent }\end{array}$ \\
\hline Afrika & 2 & 1,3 & 1,3 & 1,3 \\
Amerika & 7 & 4,5 & 4,5 & 5,8 \\
Asia & 52 & 33,8 & 33,8 & 39,6 \\
Valid Australia & 8 & 5,2 & 5,2 & 44,8 \\
Eropa & 85 & 55,2 & 55,2 & 100,0 \\
Total & 154 & 100,0 & 100,0 & \\
\hline
\end{tabular}


IDENTIFIKASI KEPUASAN FOOD TRAVELER PADA RUMAH MAKAN SARI RASA KABUPATEN ENDE (STUDI DESKRIPTIF PADA WEBSITE TRIPADVISOR) -

1)Yulius Laga, 2) Santy Permata Sari

4.3 Perbandingan level contributor terhadap Rating pada Warung Makan Sari Rasa

Tabel 3. Data Crosstabulation antara Benua terhadap Hasil Rating

Benua * Rating Crosstabulation

Count

\begin{tabular}{|c|c|c|c|c|c|}
\hline & \multicolumn{3}{|c|}{ Rating } & \multirow{2}{*}{ Total } \\
\cline { 2 - 5 } & 2,00 & 3,00 & 4,00 & 5,00 & \\
\hline Afrika & 0 & 0 & 0 & 2 & 2 \\
Amerika & 0 & 1 & 0 & 6 & 7 \\
Benua Asia & 0 & 3 & 11 & 38 & 52 \\
Australia & 0 & 0 & 1 & 7 & 8 \\
Eropa & 1 & 5 & 9 & 70 & 85 \\
Total & 1 & 9 & 21 & 123 & 154 \\
\hline
\end{tabular}
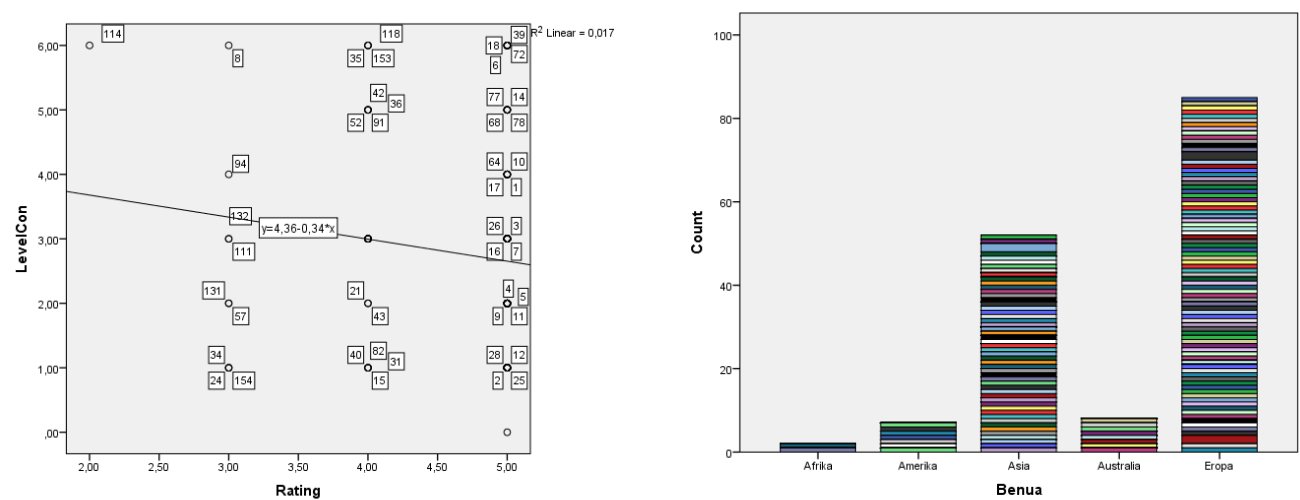

Data pada Tabel 4, menunjukan bahwa terdapat nilai rating yang rendah yang diberikan oleh food traveller asal Benua Eropa dengan alasan berdasarkan data komentar pada website TripAdvisor karena perbedaan "taste" atau rasa dan selesara yang berbeda pada menu makanan tertentu namun kasus ini hanya secara subyektif sebab melihat nilai rating maksimal atau bintang 5 juga merupakan food traveller asal Benua Eropa sebesar 70 orang yang memberikan nilai sangat memuaskan. Jadi dapat dikatakan secara umum mengenai rasa masih dapat ditolerir mengingat food traveller menyukai menu lokal dengan standar yang sesuai dengan apa yang digambarkan contributor pada website TripAdvisor. 
IDENTIFIKASI KEPUASAN FOOD TRAVELER PADA RUMAH MAKAN SARI RASA KABUPATEN ENDE (STUDI DESKRIPTIF PADA WEBSITE TRIPADVISOR) -

1)Yulius Laga, 2) Santy Permata Sari

Grafik 1. Perbandingan Level Kontributor terhadap Hasil Review Tahun 2014-2015

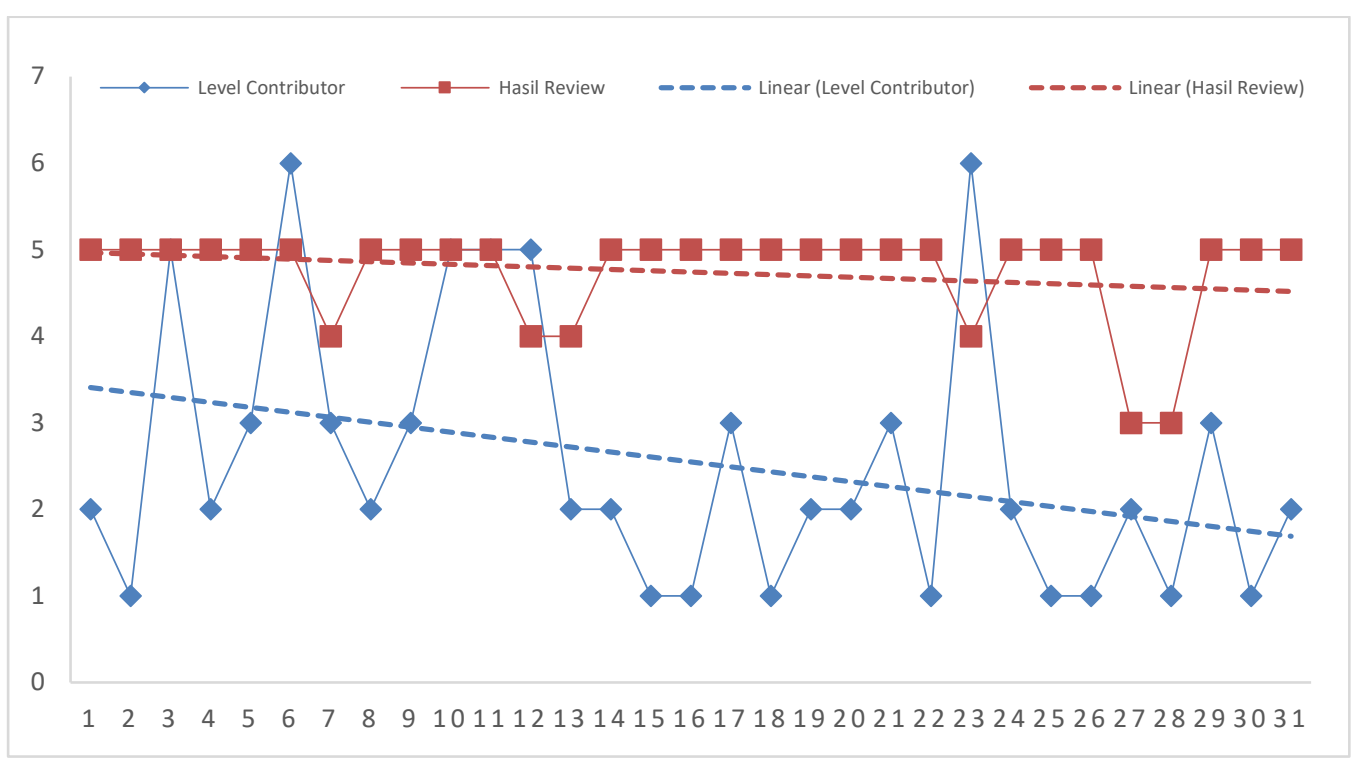

Grafik 1 menunjukan siklus yang terjadi pada tahun 2014 sampai dengan tahun 2015 bahwa terdapat perubahan kecil pada animo contributor dalam memberikan review pada kunjungan di Rumah Makan Sari Rasa. Rata-rata tren line level contributor yang cenderung menurun menunjukan penilaian yang dilakukan merupakan contributor pemula yang baru beberapa kali mereview pada website Tripadvisor. Penilaian ini rata memberikan jawaban dengan tingkat kepuasan yang cenderung stabil selama 2 tahun tersebut. Penilaian ini juga memberikan dampak pada animo food traveler selanjutnya untuk menikmati atau memilih rumah makan Sari Rasa. 
IDENTIFIKASI KEPUASAN FOOD TRAVELER PADA RUMAH MAKAN SARI RASA KABUPATEN ENDE (STUDI DESKRIPTIF PADA WEBSITE TRIPADVISOR) -

1)Yulius Laga, 2) Santy Permata Sari

Grafik 2. Perbandingan Level Kontributor terhadap Hasil Review Tahun 2016-2017

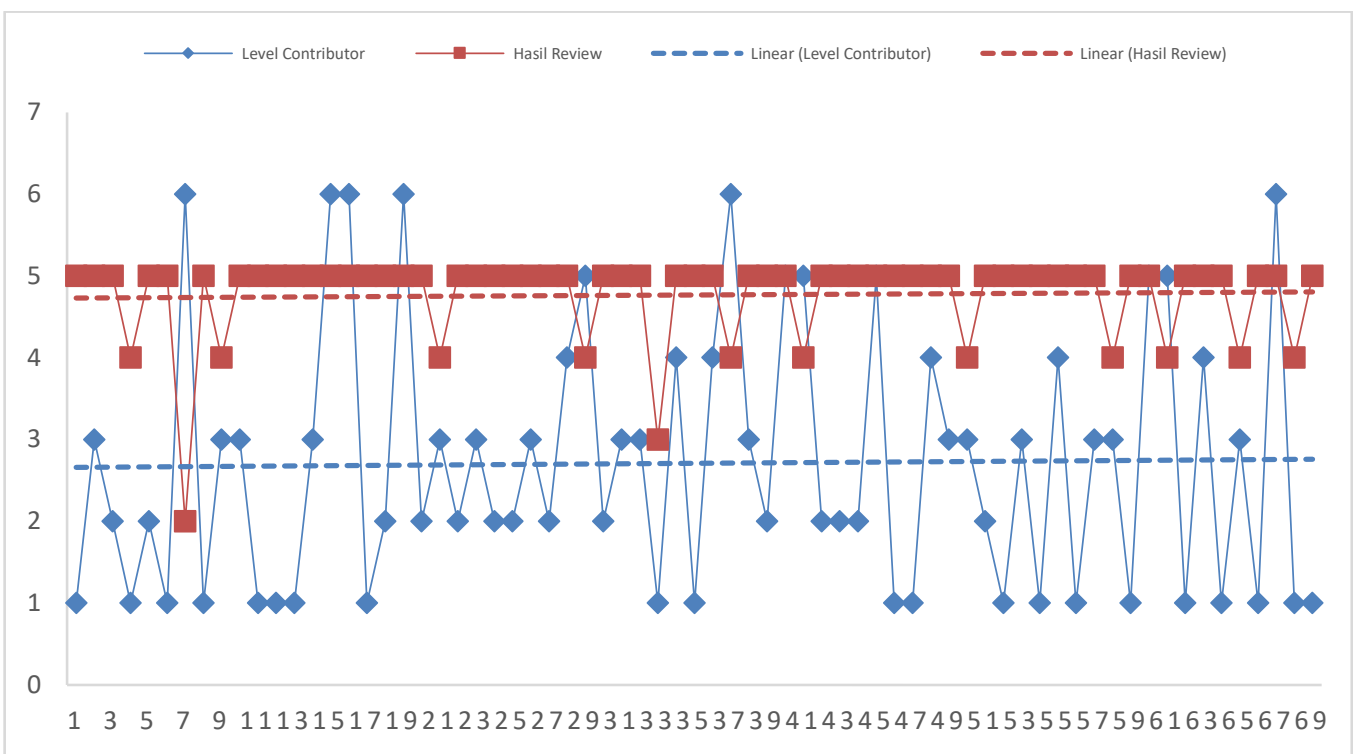

Pada grafik 2 perbandingan nilai antara level contributor terhadap nilai rating yang diberikan menunjukan intensitas yang cukup signifikan, sebab dalam waktu 2 tahun perbandingan yang sama denga 2 tahun sebelumnya animo kunjungan semakin meningkat karena ketertarikan akan informasi tentang Ruamah Makan Sari Rasa. Pada tahun 2016 sampai dengan tahun 2017, rating yang diberikan cenderung stabil pada level sangat memuaskan begitu juga nilai level contributor yang menunjukan traveller food yang sudah berpengalaman lebih intens berkunjung dan memberikan review pada Rumah Makan Sari Rasa di Kabupaten Ende, disisi lain ha ini merupakan nilai positif bagi peningkatan kunjungan wisatawan yang datang. 
IDENTIFIKASI KEPUASAN FOOD TRAVELER PADA RUMAH MAKAN SARI RASA KABUPATEN ENDE (STUDI DESKRIPTIF PADA WEBSITE TRIPADVISOR) -

1)Yulius Laga, 2) Santy Permata Sari

Grafik 3. Perbandingan Level Kontributor terhadap Hasil Review Tahun 2018-2020

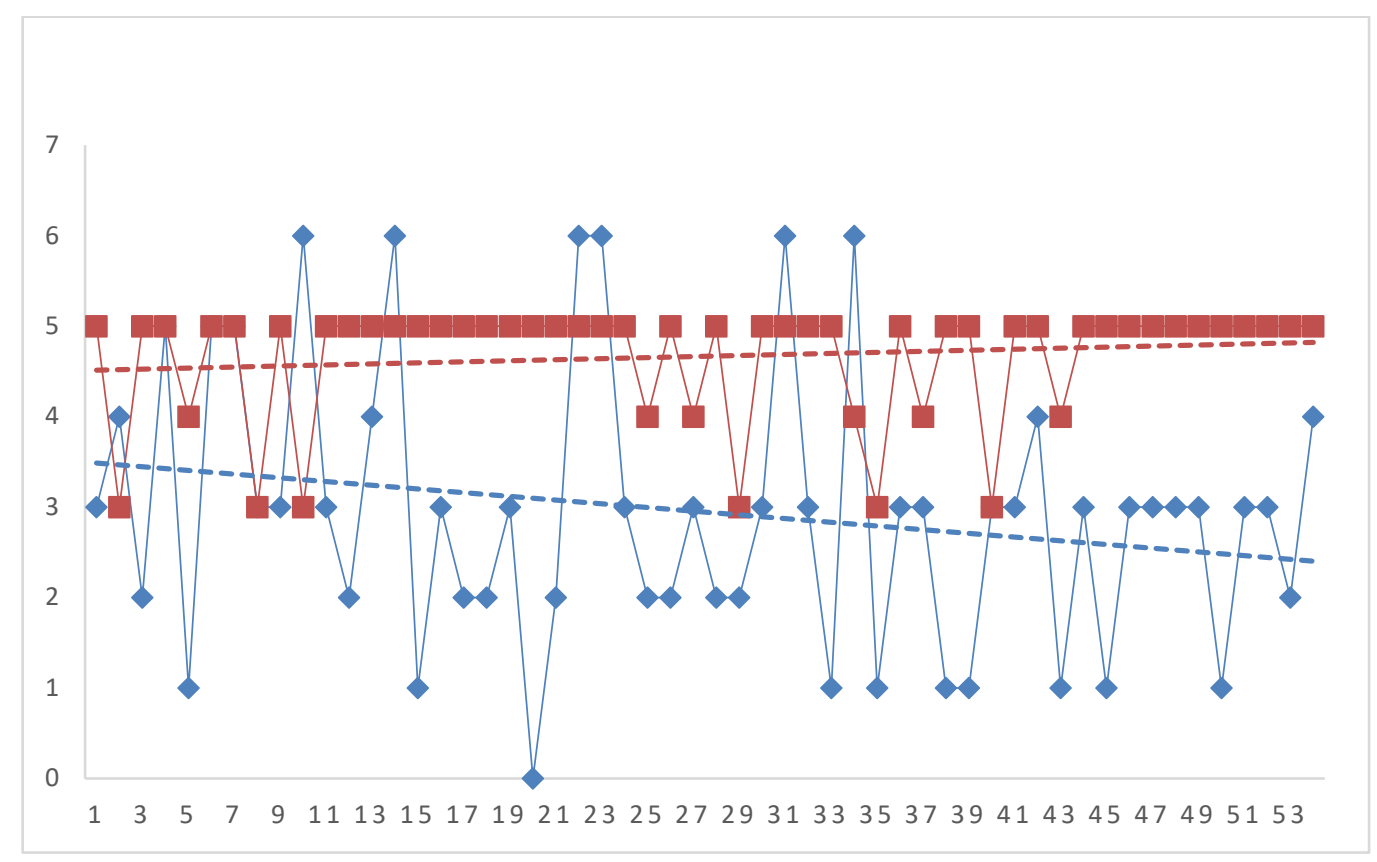

Kondisi tingkan kunjungan food traveller yang terjadi dari tahun 2018 sampai dengan awal tahun 2020, menunjukan bahwa level contributor mengalami penurunan sekalipun nilai rating tetap konsisten. Hal ini menunjukan bahwa pemerataan pada tingkat kunjungan pada Rumah Makan Sari Rasa Kabupatern Ende.

\section{Kesimpulan dan Saran}

Kesimpulan hasil analisis dari review food traveller adalah cukup puas, hal ini terbukti dengan rating yang baik, Rumah Makan Sari Rasa juga termasuk dalam kelompok warung terbaik di Asia dan di Indonesia pada Website TripAdvisor. Hal yang perlu dipertahankan adalah kualitas pelayanan (keramahan) dalam memberikan pelayanan dan kualitas menu lokal yang harus dipertahankan, disilain selama 7 tahun proses review yang dilakukan Food Traveler pada Rumah Makan Sari Rasa ternyata Food Traveler yang berasal dari Indonesia cenderung memberikan rating yang lebih rendah (cukup puas) jika dibandingan Food Traveler yang berasal dari luar negeri yang cenderung memberikan rating yang sangat puas. Atau dengan kata lain apresiasi yang cukup baik dari wisatawan asing. Beberapa hal yang menjadi catatan adalah penyesuaian rasa, misal rasa pedas pada makanan yang perlu diperhatikan, porsi makanan yang cenderung dinilai terlalu sedikit dan harga yang sebanding dengan porsi makanan yang disediakan serta perlu adanya peningkatan fasilitas dan sarana penunjang termasuk menyediakan ruangan yang nyaman pada Rumah Makan Sari Rasa. 


\section{DAFTAR PUSTAKA}

Afrizal, B. (2018). Pengaruh Kualitas Layanan Dan Harga Terhadap Kepuasan Pelanggan Warung Makan Mbah Ganis. In Magister Manajemen Institut Bisnis Nusantara.

Björk, P., \& Kauppinen-Räisänen, H. (2019). Destination foodscape: A stage for travelers' food experience. Tourism Management. https://doi.org/10.1016/j.tourman.2018.11.005

Firdaus, I. (2016). Bisni Start Up Wabaji. Universitas Bina Nusantara.

Khalida, L. R. (2018). Pengaruh Kualitas Pelayanan Dan Bauran Pemasaran Terhadap Kepuasan Pelanggan Dan Implikasinya Pada Loyalitas Pelanggan Di Rumah Makan Waroeng Desa Karawang. Jurnal Manajemen \& Bisnis Kreatif. https://doi.org/10.36805/manajemen.v3i1.237

Muhtarom, Warso, M. M., \& Hasiolan, L. B. (2015). Analisis Kualitas Pelayanan, Harga Dan Lokasi Terhadap Kepuasan Konsumen Pada Rumah Makan SBC Semarang. Journal Manajemen Pemasaran.

Situmeang, L. S. (2017). Pengaruh Kualitas Pelayanan, Harga Dan Lokasi Terhadap Kepuasan Konsumen Pada Rumah Makan Istana Hot Plate Medan. Universitas Islam Negeri Sumetera Utara.

Utami, I. A. I. S., \& Jatra, I. M. (2015). Pengaruh Kualitas Layanan Terhadap Kepuasan Pelanggan Restoran Baruna Sanur. E-Jurnal Manajemen Universitas Udayana.

Wirangga, I. W. Y., Piarsa, I. N., \& Purnawan, I. K. A. (2016). Aplikasi Sistem Informasi Geografis Untuk Pemetaan Letak Suatu Rumah Makan Di Wilayah Denpasar. Jurnal Ilmiah Merpati (Menara Penelitian Akademika Teknologi Informasi), VOL. 2(NO. 2). 